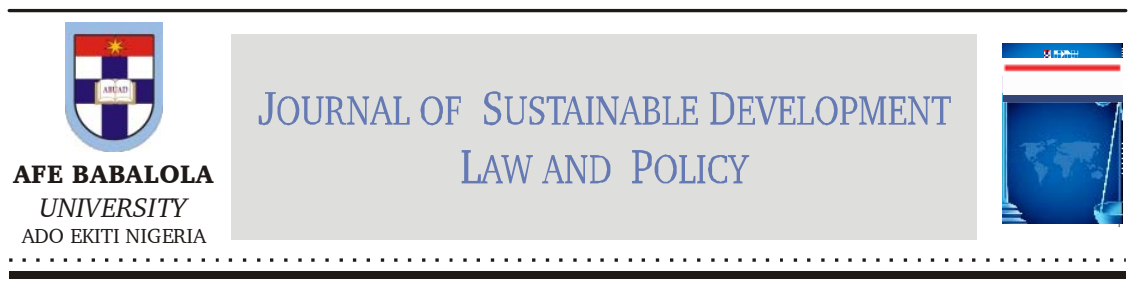

\title{
TOWARDS INNOVATIVE TEACHING PEDAGOGIES IN GENDER RESEARCH: A REVIEW OF A GENDER RESEARCH METHODS CLASS
}

\author{
Oludayo Olorunfemi*
}

\begin{abstract}
This commentary examines the teaching of research methods in Women and Gender Studies in the Gender Studies Unit of the Institute of African Studies, University of Ibadan. It interrogates how the course has increased the awareness of students in the methods of conducting research and how the research they conduct has implications on marginalized populations. The course also highlights the need for a growing body of knowledge that engages the experience of black women in Africa and the African diaspora. The course draws the attention of students to the agency of women through the reading and teaching of various research methods in Gender Studies. An ethnographic approach is adopted using participant observation in the course covering a period of one semester. Also, a critical perspective is applied in discussing the particular epistemological standpoint deployed by the course instructor. In other words, the black feminist epistemology serves as an important strategy for increasing global-minded consciousness of how a course in gender research methods engages the agency of black women using Hip Hop pedagogy.
\end{abstract}

Keywords: Gender Research Methods, Black Feminist Epistemology, Global-Minded, Black Consciousness, African Feminism.

DOI: https://dx.doi.org/10.4314/jsdlp.v11i2.11

* Gender Studies Unit, Institute of African Studies, University of Ibadan, Email: oludeester@gmail.com Phone No: 08061397690. 


\section{INTRODUCTION}

As Amina Mama once noted:

Twenty years ago, scholars who challenged andocentrism encountered strong collegial and institutional resistance, and many feminist academics paid high soil and professional cost for their trouble. Some were subjected to smear campaigns, threats and even outright violent attack for propagating ideas and concepts. Being identified as a "feminist" was considered incompatible with being a sound scholar. ${ }^{1}$

The above quote points up the difficulties people encounter in gender research in African universities where courses in Gender Studies are still few. ${ }^{2}$ This article explores the opportunities, challenges and innovations required for teaching women and gender research studies in African universities. Drawing specific examples from the teaching of research methods at the Gender Studies Unit, Institute of African Studies, University of Ibadan, the article interrogates the teaching of research methods during the second semester of the 2016/2017 academic year. The objective was to analyse step-by-step the teaching style and how knowledge was transferred to students in the gender research method class (GST 703) as a participant observer wanting to see how teaching gender helps in achieving the Sustainable Development Goal 5 (SDG 5).

Goal 5 of the United Nations Sustainable Development Goals (SDGs) is to achieve gender equality and empower all women and girl children. ${ }^{3}$ This Goal aims to end all forms of discrimination against the female gender. Teaching of gender research methods is one way to highlight the agency of women, thus putting a spotlight of the issues and challenges that continue to foster discrimination against them. ${ }^{4}$ The need to develop theories and give credence to a body of knowledge by women has valid epistemology. The pedagogy adopted by the teacher exposed students to the activism of black women over time; thus fostering the need to achieve

1 Mama, Amina, "The Challenges of Feminism: Gender, Ethics and Responsible Academic Freedom in African Universities" (2011) JHEA/RESA Vol 9 No 1\& 2 pp. 1-23.

2 Ibid.

3 Goal 5: Achieve gender equality and empower all women and girls www.un.org/ sustainabledevelopment/gender-equality/ accessed on 7 August 2020.

4 Ibid. 
SDG 5 through gender research methods.

This Gender Methods (GST 703) class was led by Dr Maria Martin, $\mathrm{PhD}$ in African and African American Studies and Professor at the University of California. This article takes a critical look at her teaching of gender research methods and how her background as an African American who identifies as a Nigerian of Igbo descent influenced the teaching and choice of materials for this class. Dr Martin had been in Nigeria on two previous occasions, so this was her third visit to the country as a scholar and researcher (Interview with Dr Maria Martin). The first time she came to Nigeria, it was as a researcher for her $\mathrm{PhD}$ thesis working on Nigerian women's movement and interrogating the lives of women activists, particularly Mrs Fumilayo Ransome-Kuti. (Interview Notes). Dr Martin's dissertation at the end of that visit was "Ojo Nro: An Intellectual History of Nigerian Women's Nationalism in Umbrella Organizations 1947-1967."

This article is divided into five sections. After this introduction, Section 2 will examine the choice of reading materials for this Gender Research Methods class. A total of 26 articles, journal papers, book chapters and scholarly papers were used as study material for this course. This section discusses the choice of the materials by the Professor and how these helped to demonstrate the necessity and transformative power of gender research. Section 3 will interrogate the choice of hip hop as an innovative method of teaching. The Professor used hip hop as a pedagogy which she calls a pedagogy of edutainment (Extract from interview). An expose on how and why she chose this medium as a teaching tool for gender research methods will be reviewed as part of the third segment of the article. Section 4 will examine the idea of black consciousness and global mindedness which was central to the class; while the fifth theme will focus on the weekly writing assignment and the class research project that each student had to undertake as part of the class assessment. The overarching theme and pedagogy for the class, Black Consciousness and Global Awareness, edifies student's perspective of gender issues and taught practical skills for research in gender and scholarly writing. All these key in with SDG 5, which is gender equality. Section 5 is the conclusion.

5 Maria A. Martin, “Ojo Nro: An Intellectual History of Nigeria Women's Nationalism in Umbrella Organizations 1947-1967." Michigan State University. African American and African Studies (2018). 


\section{INNOVATIVE TEACHING APPROACHES FOR GENDER STUDIES: GST 703 IN PERSPECTIVE}

Innovative teaching refers to teaching strategies that encourage and engage students to learn using varying method to invoke their attention, optimism, curiosity and passion for learning. ${ }^{6}$ Innovative teaching is used to motivate students to learn and progress in their knowledge of the subject matter. ${ }^{7}$ Elements of innovative teaching include the use of technology, creating a creative atmosphere for learning, facilitating interaction in the classroom, and introducing elements of day-to-day living as teaching tools. ${ }^{8}$ That way, the teacher succeeded in developing a creative thinking approach which encouraged multiple learning styles that made the learning experience most effective. All these were experienced in the gender research methods class. The students learnt about gender, gender research methods and the agency of women through multiple teaching approaches. The class had rap battles, quiz, and storytelling sessions all whipped around the teaching outcome for the course. GST 703 provided a practical example of deploying an innovative teaching approach for gender studies.

Along with the course outline, which all students received for the GST 703 Gender Methods class, was a reading list of twenty-six papers, journal articles, book chapters and other scholarly writings which were to be used to teach research methods in gender. These materials were divided into the following thematic areas: Why do gender research? Beyond feminist theory (which showed students other theories such as standpoint, intersectionality, sociological, sexuality, masculinity and grounded theories of gender research), types of research - qualitative/ quantitative, mixed methods, phenomenology, emancipatory and historical methods using narratives that centre on black women in the diaspora.

The class started with four materials which laid a background for the different approaches to Black Feminist Gender Research. In Mekgwe

6 James Davis, "Innovative Teaching Strategies that Improve Student Engagement: Five Teaching Strategies Designed to Challenge and Engage Students" www.amle.org/BrowsebyTopic/WhatsNew/WNDet/TabId/270/ ArtMID/888/ArticleID/876/Innovative-Teaching-Strategies-that-ImproveStudent-Engagement.aspx accessed 7 August 2020.

7 Ibid.

8 Ibid. 
Pinkie's Theorising African Feminism(s): The Colonial Question, ${ }^{9}$ the writer takes us through the history of African Feminism and how it fundamentally differs from the monolithic concept of Western Feminism. Filomina Chioma Steady ${ }^{10}$ defines African Feminism as "emphasising female autonomy and co-operation; nature over culture; the centrality of children, multiple mothering and kinship". The articles all tried to answer the question of what African Feminism is? The idea that feminism in the West is universal was rejected, particularly the idea of sisterhood. Oyeronke Oyewunmi ${ }^{11}$ interrogates the term "sisterhood" as a marker of white nuclear family and that "mothering is essentially an African concept".

In Ampofo et al $^{12}$ we see that Black Feminist Epistemology provides an opportunity to address commonalities and differences and forms of globalization, migration, and feminist movements and agenda. The idea that African Feminism should be African-centred was criticized in the article as there is no generic African man or woman. In an interview with Dr Martin, she posited that feminism remains a good theory for interrogating women and gender issues but there is also space to develop new theories. For example, "feminism" may not describe what women in Africa were doing in their precolonial experience.

The class did not shy away from engaging issues around sexuality in Africa. Reading Kenne Mwikya's Unnatural and Un-African: Contesting Queer phobia by Africa's Political Leadership ${ }^{13}$ alongside Hegemonic Masculinity: Rethinking the Concept ${ }^{14}$ the students had to rethink the ambiguous idea of an ideal man. We also see that homosexuality has been prevalent in African culture. Ugandan President Yoweri Museveni admitted, "Homosexuals in small numbers have always existed in our

9 Mekgwe Pinkie, “Theorising African Feminism(s): The Colonial Question", Quest: An African Journal of Philosophy 20 (1-2): 11-22 (2006).

10 Filomina Chioma Steady, "The Black Woman Cross Culturally" Schnekman Publishing Company (1981).

11 Oyewunmi, Oyeronke, "Ties that (Un) bind: Feminism, Sisterhood and Other Foreign Relations" (2001). Jenda: A Journal of Culture and African Women Studies, 11 (2001).

12 Ampofo Akosua Adomako, Josephine Beoku-Betts and Mary J. Osirim's "Researching African Women and Gender Studies: New Social Science Perspectives" (2008).

13 Mwikya, Kenne "Unnatural and Un-African: Contesting Queer phobia by Africa's Political Leadership" Feminist Africa No19 (2014), 98-105.

14 Cornell. R.W \& Messerschmidt, James W, "Hegemonic Masculinity: Rethinking the Concept" Gender and Society, Vol19, No6 (Dec 2005), pp. 829-859. 
part of Black Africa...They were never prosecuted. They were never discriminated [against]"15 this was in the wake of passing the AntiHomosexuality Act 2014 which fuelled unprecedented attacks on the LGBTQ communities across Africa. These two readings helped the students to see other theories that can be used in researching gender.

The class also engaged readings about feminist methods, qualitative, quantitative and mixed methods through the works of Sandra Harding (1987) ${ }^{16}$ Patricia Collins (1990), ${ }^{17}$ Chilisa \& Ntseane (2010). ${ }^{18}$ Maheshvri Naiu's ${ }^{19}$ empirical study on the use of female condoms in her work, "Perception around second generation female condoms: Reporting on women's experiences", chronicles the research work using quantitative methods for gender-based research. It was both an anthropological and ethnographic work which she carried out for a period of three to four months. She gave a detailed narrative of how data was collected and analysed for this study. This gave the students a guide on how to do their own project for the class. ${ }^{20}$

The readings on historical narratives on gender and global blackness in women's activism covered the dark history of women in slavery in the United States, rape, sexual violence and the civil rights movement. Revolutionary Women, Revolutionary Education: The Black Panther Party's Oakland Community School, by Ericka Huggins and Angela D. LeBlancErnest, ${ }^{21}$ showed a part of the civil rights movement which is rarely talked about because of the "conspiracy of silence" which seems to surround the agency of black women in the struggle for freedom. We studied activist women like Sojourner Truth, Mary McLeod Bethume,

15 Mwikya, Kenne "Unnatural and Un-African: Contesting Queer phobia by Africa's Political Leadership" Feminist Africa No19 (2014) 98-105.

16 Sandra Harding, Feminism and Methodology, Bloomington: Indiana University Press (1987).

17 Patricia Hill Collins, "Black Feminist Thought: Knowledge, Consciousness and the Politics of Empowerment" Hyman (1990).

18 Chilisa, Bagela \& Ntseane, Gabo, "Resisting Dominant Discourses: Implications of Indigenous, African Feminist Theory and Methods for Gender and Education Research, Gender and Education", 22:6 (2010) 617-632.

19 Maheshvari, Naidu, "Perception around Second Generation Female Condoms: Reporting On Women's Experiences" Anthropological Notebooks 19(1) (2013) 25-34.

20 Ibid.

21 Huggins, Ericka, \& LeBlanc-Ernest, Angela, "Revolutionary Women, Revolutionary Education: The Black Panther Party's Oakland Community School" Want to Start a Revolution in Radical Women in the Black Freedom Struggle New York: New York University (2009):161-184. 
Septima Clark, Ella Baker and, particularly outspoken and defiant Harriet Tubman and Fannie Lou Hamer, who risked their lives as educators during the early years of struggle by African Americans for freedom. ${ }^{22}$ The Oakland school remains one of the strongest legacy of the Black Panther Party, this could not have been with the women who ran the place and provided a support for families, particularly the children of activists who were in the struggle for freedom and emancipation of African Americans. The students, through all these readings, learnt that scholarship about gender issues, the history of the struggle of women for freedom and equality is an ongoing enterprise that is engaging the minds of Feminist Scholars all over the world.

\section{HIP HOP PEDAGOGY}

Dr Martin's choice of pedagogy for her class was derived from hip hop culture and was instructive as she used culture as an intellectual artefact. The overriding theme for the class was to be "black conscious and global minded". Hip hop culture originated from the Black community in United States and has since become a global phenomenon. The use of hip hop culture as a teaching style was strange to the students who resisted the idea of rap as a mode of theorizing. This style of teaching and engaging with students was refreshingly different. This is because Nigeria, like the rest of the world, has a growing youth population that subscribe to the hip hop culture. Therefore, to now use this culture as a learning tool was creative and practical. The use of an everyday cultural tool such as hip hop is intended to help students engage with the subject matter in relatable manner.

Hip hop pedagogy is defined as a way of incorporating the creative elements of hip hop into teaching, and inviting students to have a connection with the content while meeting them on their cultural turf by teaching to and through their realities and experiences. ${ }^{23}$ Most urban students' experiences outside school are rooted in the hip hop culture. ${ }^{24}$

22 Ibid.

23 Adjapong, E. S., \& Emdin, C, "Rethinking Pedagogy in Urban Spaces: Implementing Hip-Hop" (2015)7 Journal Urban Learning Teaching and Research, Vol. 11 66-77 (2015).

24 Emdin, C, "Moving beyond the Boat Without a Paddle: Reality Pedagogy, Black Youth, and Urban Science Education". The Journal of Negro Education (2011) 80(3), 284-295. 
The way urban students dress, talk, dance and hold non-verbal communication are all rooted in the hip hop culture. Adjapong \& Emdin recommends, "bringing hip hop culture into urban classrooms and not only incorporating it into curricula, but also incorporating the culture into the ways in which teachers teach their students." 25 The five pillars of hip hop culture are, DJaying, rapping, break dancing, graffiti art, and knowledge of self (Adjapong \& Emdin, 2015). ${ }^{26}$ These elements have been used successfully as teaching styles in both the arts, social science and sciences. The first use of the teaching method was a rap all students had to write and perform in class.

In Dr Martin's class I wrote and performed my first rap and so did all the students. The rap was an ice breaker for students to introduce themselves to the professor and vice versa. Students put thoughts into it to develop a thesis for their rap and deliver it with rhythm while not losing the message. Writing rap is not as simple as one would imagine. A lot of thought goes into the process of sounding lyrical while still speaking your truth or passing a message with the rap.

The students also did a lyrical analysis of Everytime by Wizkid featuring Future Hendrix ${ }^{27}$ and Coolest Kid in Africa by Davido featuring Nasty $\mathrm{C}^{28}$ using methods of qualitative data reduction. Wizkid and Davido are arguably the biggest hip hop icons in Nigeria having won both local and international music awards. The analysis of the lyrical data was to find common themes, compare the themes and develop a theory of how gender is represented in the songs. This analysis showed clearly how the hip hop culture strongly influences the music culture in Nigeria and how music portrays the culture of the people. Through the use of hip hop - black cultural practices that have become global - the students were exposed to a new way of engaging gender issues.

\section{BLACK CONSCIOUS AND GLOBAL MINDED}

The theme for this class was for the students to become black conscious and globally aware. Black consciousness is the awareness of one's identity

25 Adjapong, E. S., \& Emdin, C, "Rethinking Pedagogy in Urban Spaces: Implementing Hip-Hop" (2015)7 Journal Urban Learning Teaching and Research, Vol. 11 66-77. (2015).

26 Ibid.

27 Wizkid featuring Future Hendricks, "Everytime" (2017).

28 Davido featuring Nasty C, "Coolest Kid in Africa" (2016). 
as a black person, especially as a basis for a political grouping or movement. Students in the GST 703 class were all Africans whose blackness had never been a subject they needed to be conscious of when juxtaposed with other Africans in the diaspora, such as Dr Maria Martin. The idea of black consciousness in Africa was strange and, at the same time, familiar. In this class, the awareness that people are different, raised differently and have different backgrounds and experiences was illustrated when Dr Martin shared her personal journey through scholarship as a master's student in Black History in an American University.

What then did she mean when she told her gender research class to be globally aware? How globally minded could they be when the world itself was said to be shrinking into a global village? In this gender research class, we had reading materials which showed scholarship in other African countries and among the black diaspora. These we did by reading about black feminist movements, the African American struggles with race and other forms of profiling and by reading literature from other parts of Africa.

The idea of black consciousness in a gender studies class in Nigeria, the largest nation in black continent, was mind blogging at first. How more can people be conscious of the only reality they know. Nevertheless, this gender class exposed students' minds to the idea of putting their blackness in context. It helped them to appreciate and think deeply about gender issues in their own context. After all, gender issues are universal in all societies across the world. It is the contextual expression of this that makes the difference.

One of the readings was about Recy Taylor, who died a few days short of her 98th birthday on 28 December 2017, when Oprah Winfrey mentioned her in the 2018 Golden Globes acceptance speech. Oprah received the Cecil B. DeMille Award as the first black woman to be so honoured. ${ }^{29}$ Coincidentally, our reading for Dr Martin's class that week included Chapter 5, "A Life History of Being Rebellious: The Radicalism of Rosa Parks" in the collection Want to start a Revolution. ${ }^{30}$ I was to lead the class discussion on this chapter. The mention of Rosa Parks as the lead investigator in the kidnap and rape of Recy Taylor by six white men

29 The Cecil B. DeMille Award is an honorary Golden Globe Award for outstanding contribution to the world of entertainment.

30 Gore, Jeanne \& Komozi, "A Life History of Being Rebellious: The Radicalism of Rosa Parks". In: Want to Start a Revolution, NYU Press (2009), p. 115. 
who never got indicted was a shock to me.

The Rosa Parks, who was celebrated by the world, was a quiet, humble, soft spoken, and mild mannered seamstress who simply got fed up on the bus that day in Montgomery. Twenty years of activism as a member of her local National Association for the Advancement of Coloured People (NAACP) prior to the Montgomery Bus incident was wiped out so she could fit into the mould of a respectable woman. The construction of Parks' respectability proved key to the success of the boycott while obscuring her long standing politics and larger radicalism. Parks' militancy was played down in service of the movement, but this image of her as a simple seamstress would later take on a life of its own. ${ }^{31}$

Another striking feature in this reading about Rosa Parks was her attendance of the 1965 protest march at Edmund Pettus Bridge in Selma. This march was happening ten years after the bus boycott in Montgomery, yet during the march, many young organizers did not know her, and because she was not given an official jacket, the police kept pulling her out and making her stand on her side lines. (Gore, Jeanne \& Komozi 2009: 129) ${ }^{32}$ It's important to note that the whites present at the march recognized Rosa Parks and shouted out at her. In the words of Asa, ${ }^{33}$ a world famous Nigerian artiste, in her songs "Fire on the Mountain" and "Who's Responsible for What We Teach Our Children...." . There seems to be a deliberate silence and obliteration of the many contributions of women to the black liberation movement. This was an "Ahaa" moment for me in the gender research methods class. This, I concluded, was why, as women, we needed to tell our stories our way to avoid erasure. Since gender issues plague women all over Africa, we need to institutionalize gender research so we can give a voice to the silent whispers and agitation of women to tell their own stories their own way. This we can achieve by teaching gender research and writing for scholarship among students as was done in the GST703 class.

We had weekly readings which were not complete without the submission of a two-page reading reflection. In the curriculum handed to us, Dr Martin noted, "these [reading reflections] are designed to demonstrate understanding of the reading and course material and allow

31 Theoharis, Jeanne, "A Life History of Being Rebellious: The Radicalism of Rosa Parks". In: Want to Start a Revolution, NYU Press (2009).

32 Gore, Jeanne \& Komozi"A Life History of Being Rebellious: The Radicalism of Rosa Parks". In: Want to Start a Revolution, NYU Press (2009), p. 129.

33 Asa, "Fire on the Mountain" (2007). 
students to practise some of the essentials of writing such as clear communication of ideas, synthesis and analysis of information, and coherent organization." ${ }^{34}$ The very first reading reflection showed clearly that many of us had a yawning gap in writing skills. The grades were very low. Dr Martin then made extra efforts to include writing lessons into her class activities. A crash course on writing soon became a part of the three hour lectures every week. Needless to say there is a clear and distinct difference in my writing from before and after the class.

Students were expected to read about three articles and write a one page reading reflection every week following specific guidelines. The weekly writing assignment was greeted by a lot of resistance by students who found every excuse possible from complaining about the volume of reading material and the fact that it was a weekly routine. The writing assignments, though rigorous, taught me two things distinctively: how to find the thesis/ argument of the writer and, more importantly, how to be concise in review.

A major part of the grading criteria given to all students at the start of this class was the student project. Every student had to use the practical skills garnered in class to carry out a gender-based research of their own. Every student went through the process of proposal writing, going to the field, writing field notes and writing a paper based on the results of the research. This meant that gender research methods were just not taught in theory but every student put into action the knowledge that was taught in the class. I did my project by analysing antiquated gender views as expressed by Nigerian Twitter users. This project for this class laid the foundation for my Master's thesis in Gender Studies. The knowledge impacted through the practical hands-on approach of $\mathrm{Dr}$ Martin had a soothing effect on the whole learning experience.

\section{RECOMIMENDATIONS/CONCLUSION}

This article started by reviewing a Gender Research Methods class at the Institute of African Studies, University of Ibadan. This class was led by an African American scholar and researcher who brought a new perspective into doing gender research. This particular class through the choice of reading materials, class activities, weekly writing assignments, class

projects and the use of hip hop as a teaching method showed students

34 Dr Maria Martin. Syllabus for Gender Research Methods (2017). 
the need to engage gender issues as a continuum. The theme of black conscious and global awareness also demonstrated to the students that gender issues are global phenomena with which women all over the world need to engage.

The teaching of Gender Methods by Dr Martin brought a new dimension to the learning of gender issues. The interactive hands-on nature of the class and her interactions with the students made the whole learning experience very impactful. The students will remember the choice of pedagogy and the teaching style of this course for a long time. The overall effect of this kind of student engagement is an increased number of students who are equipped for effective teaching and research on gender issues. Over all, gender research will help to give a voice to women everywhere who have been conditioned by patriarchy and other forms of oppression to remain silent. Gender research will pen lines of communication about issues like rape, domestic violence, abuse, girl child (and boy child) education which affects the total fabrics of our society. Audre Lorde said, "I write for those women who do not speak, for those who do not have a voice because they are so terrified because we are taught to respect fear more than ourselves. We've been taught that silence would save us, but it won't". ${ }^{35}$ This is why we should teach gender research methods.

35 Audre Lorde, A Burst of Light and Other Essays. Ixia Press: Mineola New York (1998). 